\title{
PENGARUH EKSTRAK DAUN KEMANGI (OCIMUM BASILICUM ) SEBAGAI OBAT KUMUR TERHADAP AKUMULASI PLAK
}

\author{
Marlindayanti ${ }^{1}$, R.A. Zainur ${ }^{2}$, dan Yufen Widodo ${ }^{3}$ \\ Poltekkes Kemenkes Palembang Jurusan Keperawatan Gigi \\ marlindayanti@ymail.com
}

Diterima : 15 Juni 2018 Direvisi : 18 Juli 2018 Disetujui :19 Agustus 2018

\begin{abstract}
ABSTRAK
Plak menjadi penyebab utama penyakit gigi dan mulut, terdiri dari kumpulan bakteri yang melekat dalam suatu matrik intraceluler, dapat di kurangi dengan obat kumur yang mengandung antibakteri. Anti bakteri pada daun kemangi berupa kandungan senyawa dari minyak atsiri yaitu 1,8-cineole, ß-Bisabolene dan methyl eugenol, ketiga nya memiliki sifat larut terhadap etanol dan dapat menyebabkan kerusakan membran sel bakteri. Apabila membran sel rusak maka protein dan lipid dalam bakteri akan keluar, bahan makanan untuk menghasilkan energi tidak dapat masuk sehingga mengakibatkan kematian bakteri. Penelitian ini menggunakan ekstrak daun kemangi (Ocimum Basilicum) dengan dosis 10\%, 15\% dan $20 \%$ sebagai obat kumur. Rumusan masalahnya Apakah ekstrak daun kemangi sebagai obat kumur dapat menurunkan akumulasi plak? Merupakan penelitian eksperimental terencana, clinical trial, dengan desain paralel the pre-post test control group design. Terdapat 3 kelompok perlakuan, 1 kelompok control positif, dan 1 kelompok control negative. Jumlah sampel 50 orang dengan kriteria inklusi (rumus ferderer). Etical clearence dari Unit Etik Poltekkes Makasar. Menggunakan uji parametric Anova. Hasilnya ada perbedaan yang bermakna PHP (personal Hygiene performed) antara kontrol (+) dengan kontrol (-) ekstrak $10 \%$, dan ekstrak $15 \%(\mathrm{p}<0,05)$ namun tidak ada perbedaan dengan ekstrak $20 \%(\mathrm{p}>0,05)$. Ekstrak kemangi 20\% paling efektif dalam menurunkan akumulasi plak karena memiliki ratarata php terendah dan berbeda bermakna dibandingkan kontrol (-), ekstrak $10 \%$ dan ekstrak $15 \%$ (p<0,05). Ekstrak kemangi 20\% sama bagusnya dengan kontrol (+) dalam menurunkan akumulasi plak ( $p>0,05)$. Kesimpulan Ekstrak daun kemangi dapat digunakan sebagai obat kumur dalam menurunkan akumulasi plak.
\end{abstract}

\section{Kata kunci : Ekstrak Daun Kemangi, Akumulasi plak}

\begin{abstract}
Plaque is a major cause of dental and oral disease, consisting of a bacteria collection inherent in an intracellular matrix, may be reduced by an antibacterial mouth rinse. Anti-bacteria on basil leaves compounds of essential oils are 1.8-cineole, $\beta$-Bisabolene and methyl eugenol, all three have soluble properties to ethanol and can cause damage to bacterial cell membrane. If the cell membrane is damaged then the protein and lipid in the bacteria will come out, the food to produce energy can not enter causing the bacteriadeath. This study used basil leaf extract (OcimumBasilicum) with dose of $10 \%, 15 \%$ and $20 \%$ as mouthwash. Problem formulation does basil leaf extract as a mouthwash can decrease plaque accumulation?Experimental research planned, clinical trial, with parallel pre-post with control group design. There were 3 treatment groups, 1 positive control group, and 1 negative control group.Number of samples 50 people with inclusion criteria (federer formula). Ethical clearence of Makassar Polytechnic Ethics Unit.Using the Anova parametric test.The result was a significant difference of PHP (personal hygiene performed) between control (+) with
\end{abstract}


control (-) extract 10\%, and extract $15 \%$ (p <0.05) but no significant with extract $20 \%$ (p>0.05). The basil extract 20\%was most effective in decreasing plaque accumulation because it had the lowest average php and was significantly different than control (-), extract $10 \%$ and extract $15 \%(\mathrm{p}<0.05)$.basil extract $20 \%$ is as good as control $(+)$ in decreasing plaque accumulation ( $>0.05)$.Conclusion basil leaf extract can be used as a mouthwash in reducing plaque accumulation.

\section{Keywords: Basil Leaf Extract, Plaque Accumulation}

\section{PENDAHULUAN}

Penyakit gigi dan mulut setiap tahun meningkat, terutama karies. Data WHO (world Health Organization) menyatakan karies terjadi pada anak sekolah sebesar 60-90\%, dan hampir 100\% karies ditemukan pada orang dewasa (Ticoalu, dkk, 2013). Plak gigi memegang peranan penting sebagai penyebab terjadinya masalah utama kesehatan gigi dan mulut. Plak gigi merupakan suatu lapisan lunak tipis, tidak berwarna yang terdiri atas kumpulan mikroorganisme yang berkembang biak dalam suatu matriks dan melekat erat pada permukaan gigi. Plak dapat terbentuk kapan saja, meskipun gigi sudah dibersihkan. Pembersihan gigi yang kurang baik dapat menyebabkan plak semakin melekat. (Hamsar, 2006)

Menghilangkan plak dapat dilakukan dengan menjaga kebersihan gigi dan mulut secara teratur, melalui tindakan mekanis dan kimiawi. Membersihkan gigi secara mekanis dengan sikat gigi, sedangkan secara kimiawi menggunakan obat kumur. (Tjahja dan Lely, 2005). Di dalam kandungan obat kumur terdapat antibakteri yang bersifat bakteriostatik dan bakteriosid, sehingga obat kumur dapat menekan bakteri yang merugikan dalam mulut. Salah satu pemanfaatan efek antibakteri dari tanaman obat sebagai obat kumur yaitu menggunakan daun kemangi
(Ocimum basilicum) (Ayress et al., 1988 dalam Dewi, 2008). Daun kemangi (Ocimum basilicum) memiliki kandungan kimia seperti minyak atsiri, alkaloid, glikosida, saponin, flavonoid, triterpenoid, steroid dan tanin. Beberapa golongan kandungan kimia tersebut dapat menghambat pertumbuhan bakteri. (Sastroamidjojo S, 2001 dalam Dewi, 2008)

Salah satu bahan aktif pada daun kemangi yang berperan sebagai antibakteri adalah kandungan senyawa dari minyak atsiri yaitu 1,8-cineole, $ß$-Bisabolene, methyl eugenol. Ketiga bahan tersebut memiliki sifat larut terhadap etanol dan dapat menyebabkan kerusakan membran sel bakteri. Membran sel berfungsi untuk permeibilitas selektif dan proses transpor aktif sehingga mampu menjaga komposisi internal dalam bakteri. Apabila membran sel rusak maka protein dan lipid dalam bakteri akan keluar dan bahan makanan untuk menghasilkan energi tidak dapat masuk sehingga mengakibat kematian bakteri. (Sudarsono, dkk., 2002 dan Depkes RI, 1995 dalam Yuhana, 2010)

\section{METODE PENELITIAN}

Penelitian ini mendapat persetujuan etik dari komisi etik Poltekkes Makasar, merupakan penelitian eksperimental terencana clinic trial dengan rancangan the pre-post test control group design. Sampel 
penelitian ini adalah 50 siswa SMP IT Alfurqon Palembang yang tinggal di asrama dan telah lolos kriteria inklusi. Setiap sampel mendapat perlakuan kumur, dengan sebelumnya mengisi informed consent. 30 orang kelompok perlakuan, 10 orang kelompok kontrol positif dan 10 orang kelompok kontrol negatif. Kelompok perlakuan dengan ekstrak daun kemangi 10\% (10 orang), 15\% (10 orang) dan 20\% (10 orang). Pembuatan ekstrak daun kemangi dilakukan di laboratorium kimia Poltekkes Kemenkes Palembang Jurusan Farmasi, melalui proses maserasi ( 5 hari) dan di vakum menggunakan rotary evaporatory terhadap $2 \mathrm{~kg}$ (2000 gram) daun kemangi. Proses pengenceran menggunakan rumus M1.VI = M2.V2.

Sampel dinilai Plaknya sebelum perlakuan dan setelah perlakuan dengan
PHP (personal Higyene performer), sebelum dilakukan kumur dipastikan semua nilai PHP nol (0). Hasil akhir Data yang diperoleh 5 kelompok diuji menggunakan uji varian Anova digunakan apabila data terdistribusi normal. Data yang diperoleh dikatakan beda bermakna jika $\mathrm{p}<0,05$.

\section{HASIL DAN PEMBAHASAN HASIL}

Pengukuran PHP sebelum dilakukan penilaian sampel disuruh menyikat gigi dengan sempurna yaitu sampai semua disclosing hilang, nilai PHP disamakan baik kelompok perlakuan maupun kelompok kontrol positif dan kelompok kontrol negatif. Penilaian PHP setelah dilakukan perlakuan hasilnya sebagai berikut

Tabel 1. . Grafik rata-rata daya hambat ekstrak kemangi terhadap akumulasi plak

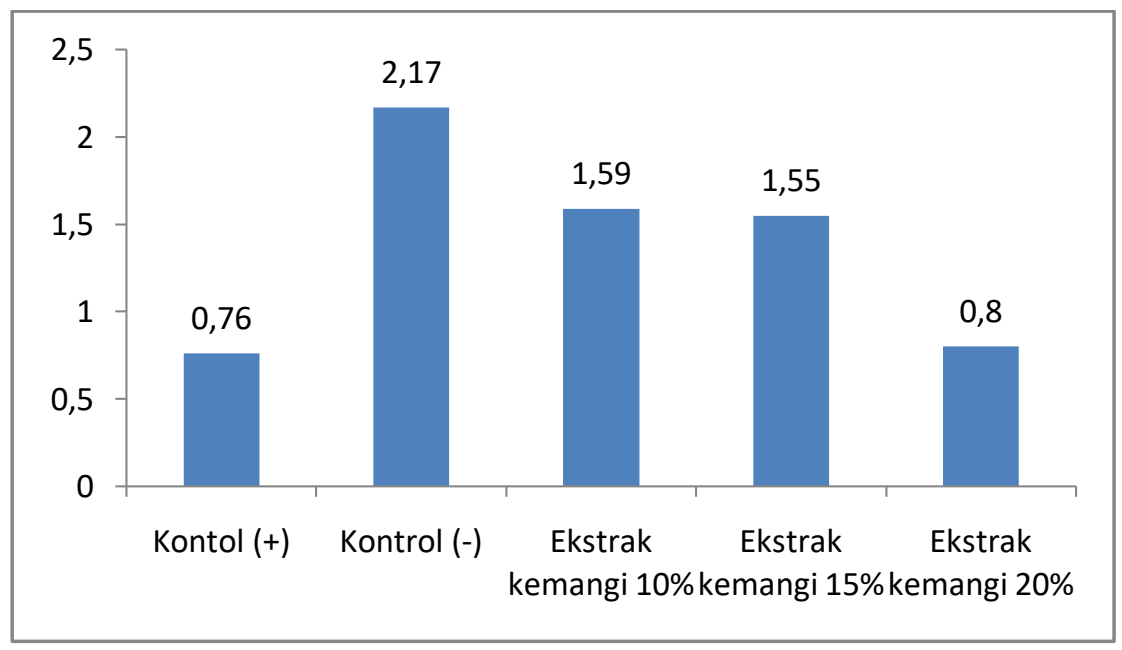

Dari tabel 1 dapat diketahui bahwa ekstrak kemangi dari konsentrasi 10\%, 15\%, dan $20 \%$ terdapat zona daya hambat terhadap akumulasi plak, semakin meningkat konsentrasinya semakin rendah akumulasi plak (PHP). Dari tabel 1 juga dapat diketahui bahwa ektsrak kemangi konsentrasi 10\% rata-rata PHP adalah 1,59 dengan kriteria baik, ektsrak kemangi konsentrasi 15\% rata-rata PHP adalah 1,55 dengan kriteria baik, dan ektsrak kemangi konsentrasi 20\% rata-rata PHP adalah 0,8 dengan kriteria sangat baik. Pada kontrol positif 
yaitu obat kumur yang mengandung chlorhexidine memiliki rata-rata PHP adalah 0,76 dengan kriteria sangat baik, dan kontrol negatif yaitu aquades steril memiliki rata-rata PHP adalah 2,17 dengan kriteria sedang.

Tabel 2. Hasil uji one way ANOVA

\begin{tabular}{|c|c|c|c|c|c|}
\hline & $\begin{array}{c}\text { Sum of } \\
\text { Squares }\end{array}$ & df & Mean Square & F & Sig. \\
\hline Between Groups & 14,177 & 4 & 3,544 & 8,230 &, 000 \\
Within Groups & 19,379 & 45 &, 431 & & \\
Total & 33,556 & 49 & & & \\
\hline
\end{tabular}

Dari uji one way ANOVA didapatkan $\mathrm{F}$ hitung 8,230 > F tabel 2,579, dengan demikian $\mathrm{H}_{0}$ ditolak, artinya terdapat perbedaan PHP dari kelima kelompok perlakukan, hal ini menunjukkan bahwa ekstrak kemangi dapat menurunkan akumulasi plak (PHP). Selain itu didapatkan $\mathrm{p}=000(\mathrm{p}<0,05)$, dapat disimpulakn bahwa ada perbedaan akumulasi plak (PHP) diantara kelompok kontrol ekstrak kemangi konsentrasi 10\%, 15\%, 20\%, serta kelompok kontrol positif (lampiran). Dilanjutkan dengan Post Hoc dengan Least Significant Difference (LSD) untuk mengetahui sebesar besar perbedaan antara kelompok konsentrasi ekstrak kemangi 10\%, 15\%, 20\% dengan kontrol positif.

Tabel 3. Hasil uji Post Hoc daya hambat ekstrak kemangi konsentrasi 10\%, 15\%, $20 \%$

\begin{tabular}{|c|c|c|c|c|c|c|}
\hline \multirow[b]{2}{*}{ (I) Kelompok } & \multirow[b]{2}{*}{ (J) Kelompok } & \multirow{2}{*}{$\begin{array}{c}\text { Mean } \\
\text { Differenc } \\
\text { e (I-J) }\end{array}$} & \multirow[b]{2}{*}{$\begin{array}{l}\text { Std. } \\
\text { Error }\end{array}$} & \multirow[b]{2}{*}{ Sig. } & \multicolumn{2}{|c|}{$\begin{array}{l}\text { 95\% Confidence } \\
\text { Interval }\end{array}$} \\
\hline & & & & & $\begin{array}{l}\text { Lower } \\
\text { Bound }\end{array}$ & $\begin{array}{l}\text { Upper } \\
\text { Bound }\end{array}$ \\
\hline \multirow[t]{4}{*}{ Kontol (+) } & Kontrol (-) & $-1,41000^{*}$ & ,29348 &, 000 & $-2,0011$ &,- 8189 \\
\hline & Ekstrak kemangi $10 \%$ &,$- 83000^{*}$ & ,29348 & ,007 & $-1,4211$ &,- 2389 \\
\hline & Ekstrak kemangi $15 \%$ &,$- 79000^{*}$ & ,29348 &, 010 & $-1,3811$ &,- 1989 \\
\hline & Ekstrak kemangi $20 \%$ &,- 04000 & ,29348 & ,892 &,- 6311 &, 5511 \\
\hline \multirow[t]{4}{*}{ Kontrol (-) } & Kontol $(+)$ & $1,41000^{*}$ & 29348 &, 000 & ,8189 & 2,0011 \\
\hline & Ekstrak kemangi $10 \%$ & ,58000 & ,29348 & 054 &,- 0111 & 1,1711 \\
\hline & Ekstrak kemangi $15 \%$ &, $62000^{*}$ & ,29348 & 040 & ,0289 & 1,2111 \\
\hline & Ekstrak kemangi $20 \%$ & $1,37000^{*}$ & ,29348 &, 000 & ,7789 & 1,9611 \\
\hline Ekstrak & Kontol (+) &, $83000^{*}$ & 29348 & ,007 & ,2389 & 1,4211 \\
\hline \multirow[t]{3}{*}{ kemangi $10 \%$} & Kontrol (-) &,- 58000 & ,29348 &, 054 & $-1,1711$ & ,0111 \\
\hline & Ekstrak kemangi $15 \%$ & ,04000 & 29348 & ,892 &,- 5511 & ,6311 \\
\hline & Ekstrak kemangi $20 \%$ &, $79000^{*}$ & ,29348 &, 010 &, 1989 & 1,3811 \\
\hline Ekstrak & Kontol (+) &, $79000^{*}$ & 29348 & $\overline{, 010}$ & , 1989 & 1,3811 \\
\hline \multirow[t]{3}{*}{ kemangi $15 \%$} & Kontrol (-) &,$- 62000^{*}$ & ,29348 &, 040 & $-1,2111$ &,- 0289 \\
\hline & Ekstrak kemangi $10 \%$ &,- 04000 & ,29348 & ,892 &,- 6311 &, 5511 \\
\hline & Ekstrak kemangi $20 \%$ &, $75000^{*}$ & ,29348 &, 014 &, 1589 & 1,3411 \\
\hline Ekstrak & Kontol (+) &, 04000 & ,29348 & ,892 &,- 5511 &, 6311 \\
\hline
\end{tabular}




\begin{tabular}{|c|c|c|c|c|c|c|}
\hline kemangi $20 \%$ & $\begin{array}{l}\text { Kontrol (-) } \\
\text { Ekstrak kemangi } 10 \% \\
\text { Ekstrak kemangi } 15 \%\end{array}$ & $\begin{array}{r}-1,37000^{*} \\
-, 79000^{*} \\
-, 75000^{*}\end{array}$ & $\begin{array}{l}, 29348 \\
, 29348 \\
, 29348\end{array}$ & $\begin{array}{l}, 000 \\
, 010 \\
, 014\end{array}$ & $\begin{array}{l}-1,9611 \\
-1,3811 \\
-1,3411\end{array}$ & $\begin{array}{l}-, 7789 \\
-, 1989 \\
-, 1589\end{array}$ \\
\hline
\end{tabular}

$*$. The mean difference is significant at the 0.05 level.

adalah 0,8 dengan kriteria sangat baik.

\section{PEMBAHASAN}

Hasil Analisis uji $\mathrm{LSD}_{0,05}$ (tabel 3) menunjukkan ada perbedaan yang bermakna antar kelompok $(\mathrm{p}<0,05)$ pada kontrol positif dan kontrol negatif, ekstrak kemangi konsentrasi 10\%, 15\%, $20 \%$. Kontrol negatif dengan kontrol possitif , ekstrak kemangi konsentrasi 10\%, 15\%, $20 \%$. Ekstrak kemangi 10\% dengan kontrol positif, kontrol negatif, ekstrak kemangi konsentrasi $15 \%$ dan $20 \%$. Ekstrak kemangi $15 \%$ dengan kontrol positif , kontrol negatif, ekstrak kemangi konsentrasi $10 \%$ dan 20\%. Ekstrak kemangi $20 \%$ dengan kontrol positifm kontrol negatif, ekstrak kemangi $10 \%$ dan $15 \%$.

Hasil penelitian menunjukkan bahwa ekstrak kemangi konsentrasi $10 \%$, $15 \%, 20 \%$ memiliki efek daya hambat akumulasi plak (PHP). Perbedaan daya hambat ini diuji secara statistik dengan menggunakan uji one way ANOVA. Hasil uji tersebut menunjukkan adanya daya hambat yang bermakna dari ekstrak kemangi konsentrasi 10\%,15\%, dan 20\% terhadap penurunan akumulasi plak (PHP).

Dari sistem klasifikasi pada tabel 1 mengenai respon daya hambat, maka ekstrak kemangi konsentrasi 10\%,15\%, dan $20 \%$ memiliki respon daya hambat kuat, hal ini ditandai dengan rata-rata akumulasi plak (PHP) pada ekstrak kemangi $10 \%$ adalah $1,59 \%$ dengan kriteria baik dengan $\mathrm{kr}$, ekstrak kemangi $15 \%$ rata-rata akumulasi plak (PHP) adalah 1,55 dengan kriteria baik, esktrak $20 \%$ rata-rata akumulasi plak (PHP)
Obat kumur yang mengandung chlorhexidine sebagai kontrol positif memiliki respon daya hambat yang kuat terhadap akumulasi plak (PHP), sama halnya bahan ekstrak kemangi dengan konsentrasi $20 \%$.

Daun kemangi mengandung apigenin yang merupakaan kelompok flavonoid yang memiliki efektifitas daya antibakteri terhadap streptococcus mutans - Apigenin yang juga dikenal sebagai Chamomile, Apigenol, Spignenin, Versulin, 4', 5, 7- Trihydroxyflavone ini bersifat antibakteri terhadap streptococcus mutans. Senyawa apigenin juga bersifat kariostatik yang merupakan suatu kemampuan dalam mengurangi produksi asam oleh bakteri dalam plak dengan cara mengahmbat kerja enzim yang berhubungan dengan pertumbuhan dan proses glikosis streptococcus mutans, sehingga mencegah pemecahan sukrosa dan mengahambat proses gilkolisis yang dapat mengahasilkan asam yang dapat merusak gigi.

Salah satu bahan aktif pada daun kemangi yang berperan sebagai antibakteri adalah kandungan senyawa dari minyak atsiri yaitu 1,8-cineole, B-Bisabolene, methyl eugenol. Ketiga bahan tersebut memiliki sifat larut terhadap etanol dan dapat menyebabkan kerusakan membran sel bakteri. Membran sel berfungsi untuk permeibilitas selektif dan proses transpor aktif sehingga mampu menjaga komposisi internal dalam bakteri. Apabila membran sel rusak maka protein dan lipid dalam bakteri akan keluar dan bahan makanan untuk menghasilkan energi tidak dapat 
masuk sehingga mengakibat kematian bakteri. (Sudarsono, dkk., 2002 dan Depkes RI, 1995 dalam Yuhana, 2010)

\section{KESIMPULAN}

Kesimpulan hasil penelitian
diketahui bahwa semakin tinggi
konsentrasi ekstrak daun kemangi,
akumulasi plak semakin berkurang,
ekstrak daun kemangi konsentrasi $20 \%$
sudah dapat menyamai kontrol positif
dalam menurunkan akumulasi plak (PHP).
Ekstrak daun kemangi dapat menurunkan
akumulasi plak.

\section{REFERENSI}

Dewi, Dian Puspita. 2008. Pemisahan Minyak Atsiri Daun Kemangi (Ocimum basilicum) secara kromatografi Lapis Tapis dan Aktivitasnya Malassezia furfur in vitro. Fakultas Kedokteran UNDIP Semarang

Sastroamidjojo S. Obat asli Indonesia. Ed 6. Jakarta: Dian Rakyat; 2001. p. 141

Hamsar, Adriana. 2005. Perbandingan Sikat Gigi yang Berbulu Halus (Soft) dengan Sikat Gigi yang Berbulu Sedang (Medium) terhadap Manfaatnya Menghilangkan plak pada Anak Usia 9-12 Tahun di SD Negeri O60830 Kecamatan Medan Petisah Tahun 2008. Jurnal Ilmiah PANMED USU vol.1 No 1 Juli 2006 hal. 20-23

Yuhana, Sinchia Ayu. 2010. Antibakteri Ekstrak Daun kemangi (Ocimum sanctum Linn.) terhadap bakteri Aeromonas hydrophila secara in vitro. Surabaya. Universitas Airlangga
Departemen Kesehatan Republik Indonesia. 1995. Materia Medika Indonesia Jilid VI. Jakarta: Departemen Kesehatan Republik Indonesia.

Sudarsono, Gunawan D., Wahyuono S., Donatus IA., Purnomo. 2002. Tumbuhan obat II (hasil penelitian, sifat-sifat, dan penggunaannya). Yogyakarta : Pusat Studi Obat Tradisional Universitas Gadjah Mada.).

Lely S., Made Ayu dan Tjahja N, Indirawati. 2005. Hubungan Kebersihan Gigi dan Mulut dengan Pengetahuan dan Sikap Responden di Beberapa Puskesmas di Jawa Barat. Media Litbang Kesehatan Vol. XV No. 4 Tahun 2005

Widyani, Dien. 2011. Pengaruh Ekstrak Etanol Daun Kemangi terhadap pertumbuhan Staphylococcus aureus secara in vitr. FK Universitas Islam Sultan Agung

Bakar, Abu. 2002. Kedokteran Gigi Klinis. Yogyakarta: Quantum

Afrensi, Oktavia Dhiosi. 2007. Pengaruh Minyak Atsiri Kemangi terhadap Investasi Larva Lalat Hijau pada Ikan Mas. Bogor: departemen Ilmu Penyakit Hewan dan Kesehatan Masyarakat Veteriner FKH IPB

Hendrawati , Anindita Rosenda Eka.2009. UJI TOKSISITAS AKUT EKSTRAK ETANOL DAUN KEMANGI ( Ocimum sanctum Linn. ) TERHADAP LARVA Artemia salina Leach DENGAN METODE BRINE SHRIMP LETHALITY TEST ( $B S T$ ). Semarang: Fakultas Kedokteran UNDIP 
Ticoalu. RL, Wicaksono, D.A, dan Zuliari, K, 2013, Gambaran Kebutuhan Perawatan Karies Gigi pada Siswa Sekolah Menengah Atas di Kecamatan Lembeh Selatan Kota Bitung. Jurnal e-Gigi. Universitas Sam Ratulangi Manado 